\title{
FEATURES OF CULTURAL AND RELIGIOUS TRADITIONS OF THE ARMENIAN PEOPLE
}

\author{
(C) Mariam I. Adzhemian, Yulia A. Petrova \\ Rostov State University of Economics, Rostov-on-Don, Russian Federation \\ science-almanac@mail.ru
}

\begin{abstract}
The article reveals the concepts of "religiosity" and "Armenian religious identity" in modern Armenia, some examples of the Armenian national religion. In particular, the traditions of Armenian apostolic Christianity and its folk versions, expressed in religious holidays and rites, are considered. Armenians are one of the oldest peoples of the world, the documentary history of which dates back about three millennia and Armenia was the first country where Christianity was proclaimed as a state religion. For such a long time, the people have repeatedly experienced tragic periods of their history, and periods of unprecedented heyday, and creative work. The national features of the character of Armenians usually include hard work, determination, energy, resilience, entrepreneurship. They have a special addiction to teaching and crafts, respect for written culture, devotion to their language, home and family. This people is characterized by irascibility and self-love, combined with good-natured peacefulness, hospitality, love of music and subtle humor; they are easily appeased. At the same time, Armenians are characterized by developed individualism, unwillingness to submit to anyone, this allowed them to preserve their culture and religion, which have been vividly embodied in the customs and traditions of religious and secular character of this ethnic group and which are significant to this day.

Key words: religion, Armenian Apostolic Church, Christianity, identity, religious holidays.
\end{abstract}

\section{[М.И. Аджемян, Ю.А. Петрова Особенности культурно-религиозных традиций армянского народа]}

Статья раскрывает понятия «религиозность» и «армянская религиозная идентичность» в современной Армении, некоторые образцы армянской национальной религии. В частности, рассматриваются традиции армянского апостольского христианства и его народных версий, выраженных в религиозных праздниках и обрядах. Армяне - один из древнейших народов мира, документальная история которого насчитывает около трех тысячелетий. а Армения была первой страной, где христианство было провозглашено как государственная религия. На протяжении столь длительного времени народ не раз переживал и трагические периоды своей истории, и периоды небывалого расцвета, и созидательного труд. К национальным чертам характера армян обычно относят трудолюбие, целеустремленность, энергичность, жизнестойкость, предприимчивость. Им присуще особое пристрастие к учению и ремеслам, уважение к письменной культуре, преданность своему языку, дому и семье. Данному народу присуще вспыльчивость и самолюбие, в сочетании с отходчивостью, добродушием миролюбием, гостеприимством, любовью к музыке и тонкому юмору. В то же время для армян характерен развитый индивидуализм, нежелание подчинятьсякому-либо, что позволило им сохранить свою культуру и религию, которые получили яркое воплощение в обычаях и традициях религиозного и светского характера данного этноса и значимы по сей день.

Ключевые слова: религия, Армянская Апостольская Церковь, христианство, идентичность, религиозные праздники.

Mariam I. Adzhemian - Student, Rostov State University of Economics, Rostov-on-Don, Russian Federation. Yulia A. Petrova - Ph.D. in Philosophy, Associate Professor, Rostov State University of Economics, Rostovon-Don, Russian Federation.

Аджемян Мариам Ишхановна - студентка, Ростовский государственный экономический университет, г. Ростов-на-Дону, Российская Федерация.

Петрова Юлия Андреевна - кандидат философских наук, доцент, Ростовский государственный экономический университет, г. Ростов-на-Дону, Российская Федерация. 
Armenia was the first country where Christianity was proclaimed as a state religion. This turning point in the history of Armenia occurred in $301 \mathrm{AD}$, during the reign of the great Armenian king Tiridates III (287-330) and was fixed by the efforts of Gregory the Illuminator (302-326). This historical act was crucial for the further development of the Armenian people, its socio-political life and spiritual culture. Since then, the Armenian people and its faith have become indivisible. Christian faith crystallized, turned into black blood, so that the self-sacrificing ancestors of the Armenians turned their faith into their skin, boldly professing that "neither angels, nor people, nor fire and sword can tear the Armenians from this faith." Dictators of other religions and peoples have had to put up with this fact for centuries. The role of the Armenian church in the creation and preservation of the national identity of the Armenian people is invaluable, since the definition of the national church is given to it by the Armenian people.

There are religious holidays of the Armenian people, such as: "Christmas," "Easter," "Vardavar," "Wedding Ceremony," "Baptism," "Trndez," as well as cultural features that "reflect the personality and temperament, roles and relationships, social and ethnic identity" [1], social forms of religion, systems of signs and images of the religious mentality of the Armenian people. The main symbols of the Armenian religious identity are the Armenian apostolic doctrine, liturgy and ritual, church architecture, priesthood, Catholicos (the head of the Armenian Church), hach'kar's (khachkars), Mother See of Holy Etchmiadzin (the governing body of the Armenian Apostolic Church and the residence of the Armenian Catholicos), and many others, which at the same time are considered the most applicable symbols of the Armenian identity [4].

Considering the cultural and religious characteristics of the Armenian people, it should be noted that Armenians are a traditional nation and have many traditions that are passed down from generation to generation. Thus, in contrast to the Catholic and Orthodox churches, which celebrate Christmas on the 25th of December and on the 7th of January, the Armenian Apostolic Church celebrates it on the 6th of January. Christmas is preceded by a post that begins on the 30th of December and ends in the evening on the 5th January. Holy Christmas is the birthday of Jesus, and all the Christian peoples of the world celebrate it. On Christmas morning, the family meets together at the table, everybody has had a bath and dressed in new clothes. The Armenian people are known for their hospitality, warmth and peace, but it is this day that they celebrate Christmas morning in a narrow circle of the family. The main Christmas dishes of the table are fish snacks: boiled, fried, fish pies, fried fish, etc. In addition to fish products, there is pilaf from rice, noodles, hashil from flour and sweetened with doshab or honey, soup with peas and dried vegetables, known as "sunset" [2].

The Armenian Apostolic Church celebrates the holiday of Easter (Easter Sunday). Greeting each other on Easter, the followers of the Armenian Apostolic Church say: "Christ aryav and merelots" ("Christ is risen from the dead") and answer: "Ornyalearutyune Christ" ("Christ Sunday is Blessed"). In the houses of Armenians, according to all traditions, an Easter table is laid. On the table there is boiled fish, dishes from herbs, pilaf with raisins and red-colored eggs, in memory of the fact that the world was saved by the price of Christ's blood. The Armenian families celebrate Easter with a special feeling.

The history of the "Vardavar" holiday. Later, after the adoption of Christianity, the holiday symbolized the Transfiguration of Christ, and the filling with water on each other symbolized purification from sins. The "Vardavar" holiday is celebrated on the 14th Sunday after Easter, as a rule, takes place in July, that is, on the hottest summer days. In the morning, a liturgy is held in all churches dedicated to the transfiguration of Christ, the glorying of water and the blessing of fruits (an apple is a symbol of the holiday). On the "Vardavar" holiday in Yerevan and in the regions, theatrical performances are organized that represent national 
games, songs, dances, as well as historical and cultural monuments preserved from the preChristian period of Armenia.

Customs and traditions specific to the Armenian people were formed as a result of centuries. It is generally accepted that the Armenians are warm, positive and sincere people. The Armenians take great care of their children and put the family before all else.

Wedding ceremonies are usually large celebrations, previously weddings lasted 7 days and 7 nights. The Armenian youth usually marry only with the consent of their parents. The groom's parents visit the bride's family and conclude an oral agreement. This phenomenon from the literal translation is "take the word." The Armenians also believe that church marriage is the most important thing. The wedding ceremony consists of several parts: collusion, betrothal and the wedding celebration itself. Witnesses at the Armenian wedding are "godparents of the wedding." The closest and most respected couple from the environment of the bride and groom is asked to become the godparents of the wedding, it is believed that they are responsible for the new family from the day of its formation to the very end [3].

On the morning after the wedding, a red apple is brought to the bride's house. Thus, women of the husband's family confirm the innocence of the bride. At the wedding, the bride is given a child to hold, it must be a boy, since it is believed that this will predefine the gender of the couple's first child. Traditionally, the Armenian families are large. The birth of a child in the family was always gladness. But the birth of a boy was special gladness.

Baptism in the Armenian Apostolic Church has its own characteristics and traditions. A person of any age can pass the sacrament. Most often, the ceremony is carried out in infancy, after 40 days of the birth of the child, since the baby is not shown to anyone but loved ones up before 40 days.

For baptism, the parents of the child choose the godfather. Only a man, an Armenian baptized in the Armenian Church, can be a godparent in the Armenian Church, which is a prerequisite. He must possess spiritual knowledge in order to educate the godson according to the God's commandments and the Armenian national traditions. Before the sacrament, it is necessary to purchase a baptismal cross and a rope for it [8]. It must be made of interweaving red and white threads. The rope is called "narot," and the threads of these colors are symbols of blood that has come from the rib of Christ and water. For the procedure, you need to take a towel and a shirt, which are snow-white baptismal clothes. Forehead, eyes, ears, nostrils, mouth, chest, back and legs of the newly baptized are anointed. Each part of the body is anointed with a special prayer. In conclusion, a godfather with a newly baptized child worship the holy throne. Communion of the Holy Secrets in the Armenian Church is necessarily performed immediately after the baptism. Three days later, the godfather must bathe the child in ordinary water. All the same happens to adults.

After the adoption of Christianity, Trndez was linked to one of the main church holidays, Presentation of Christ. The Armenian Apostolic Church annually celebrates the Presentation of Christ or Tjarnendarach (meeting with the Creator) on the 40th day after the Epiphany, on the 14th of February. The Armenian Church celebrates the Epiphany as a single holiday of Christmas and the Epiphany on the 6th of January [7].

According to the Old Testament law, the woman who gave birth to a boy was forbidden to enter the God's temple for 40 days. After this time, she came to the temple with a baby, to thank the Lord. An ancient elder came out (Simeon, to whom the Holy Spirit foretold that he would not die until he sees the Savior) towards the God's Mother, who stepped over the temple threshold with the baby in the hands. According to the church constitution, on the eve of the holiday, after the end of the evening sacred service, the ceremony of making holy of the four corners of the earth is performed (Andastan) and then, the ceremony of blessing the candle. According to the oldest tradition dating back to the pre-Christian era, a bonfire 
symbolizing the saving light of Christ is made from a blessed candle, and newlyweds and lovers jump through the fire holding their hands. People believe that if couples can jump over the fire three times without separating their hands, their family will be strong, and love will be eternal. As a guarantee of happiness and well-being, newlyweds, according to the tradition, are showered with wheat and hemp seeds. Childless women traditionally jump through the fire in the hope of acquiring offspring, as well as other Trndez participants, in order to attract luck and prosperity. Then everyone dances around the bonfire. On Trndez, according to the tradition, bonfires are made both in the streets and in the courtyards of houses in the cities and villages of Armenia, through which everyone jumps. This tradition gives special joy to children and young people. On Trndez in Armenia you can see an unusually romantic spectacle, late in the evening, young men and girls walk holding glasses with small candles.

In rural areas, ash left from fires is collected and scattered around the fields so that the year is successful and the crop is good. The feast of the Presentation of Christ was declared as the Day of blessing of the newlyweds by Catholicos of All Armenians Garegin II. In all Armenian churches, according to the tradition, on the 14th of February, after the festive liturgy of Tjarnendarach, the ceremony of blessing of the young is held [6].

The presented materials allowed us to show the ethnic traditions of the Armenian people in different spheres of culture through the prism of religious identity in modern Armenia. Some of these traditions have their origin since ancient times, others date back to later periods, having formed at each stage from the innovations that arose during the historical process.

Further research in the field of culture will help transfer the idea of human consciousness into the unity with ethnocultural, social values and traditions. This will determine the nature of the evolution of spiritual culture, the cultural connection of generations [5]. The ethnic identity of the Armenian culture emerged as a complex system, which was always in the sphere of interaction between different peoples, but has retained its originality. Having carefully preserved and enriched their own culture, the Armenian people made a worthy contribution to the common cultural treasury of the peoples of the earth. Due to the historical circumstances, the Armenian cultural and religious traditions developed not only in the homeland, Armenia, but also in the Armenian diasporas around the world, being for centuries the strongest support that unites the Armenians and preserves their identity. The Armenian culture and religion are a combination of material and spiritual values created by the Armenian people.

\section{Лumepamypa}

1. Краткая история армянского народа (Возникновение Армении), URL: https://lookarmenia.am/ru/armenia/obchie-svedeniya/istoriya (Дата обращения 3.07.2020).

2. Народное творчество (Фольклор) «Армянская свадьба». URL: https://www.libfox.ru/668886-narodnoe-tvorchestvo-folklor-armyanskaya-svadba.html (Дата обращения 17.07.2020).

3. Харатян Г.С (также, Г.С Аракелян) «Армянские народные праздники, Ереван 200, URL: http://geopolitika.am/dir/wp-content/blogs.dir/1/files/2015_1_2_34_44.pdf (Дата обращения 15.07.2020) .

4. Шагинян Мариэтта. Путешествие по советской Армении [Электронный ресурс], URL: https://www.litmir.me/br/?b=139187\&p=1 (Дата обращения 22.07.2020).

5. Antonyan Y. Religiosity and religious identity in Armenia: Some current models and developments. Article in Acta Ethnographica Hungarica, December 2011. DOI: 10.1556/AEthn.56.2011.2.4. 
6. Lisitsian S.S. Ancient dances and theatrical performances of the Armenian people.1958, no. 5, p. 131-138

7. Petrova J. A. Cultural and Language Problems Faced by Migrants as The Members of a Certain Ethnic Community. Retrieved from, [Electronic resource], URL:http://sciencealmanac.ru/documents/72/2016-01-14-Petrova.pdf (дата обращения 18.07.2020).

8. Petrova Yulia A., Kemova Milana R. Adygea Is a Pearl of the Caucasus, National Features of Ethnos from Origins to Modernity. URL: http://science-almanac.ru/documents/285/2019-04-05-Kemova-Petrova.pdf (Дата обращения 25.07.2020).

\section{References}

1. Kratkaia istoriia armianskogo naroda (Vozniknovenie Armenii). [Brief History of the Armenian People (Origin of Armenia)]. Available at: https://lookarmenia.am/ru/armenia/obchie-svedeniya/istoriya (accessed 7 July 2020) (in Russian).

2. Narodnoe tvorchestvo (Folklor) "Armianskaia svadba". [Folk art (Folklore) "Armenian Wedding"]. Available at: https://www.libfox.ru/668886-narodnoe-tvorchestvo-folklorarmyanskaya-svadba.html (accessed 17 July 2020) (in Russian).

3. Haratyan G.S. (also, G.S. Arakelyan) "Armianskie narodnye prazdniki, Erevan 200". ["Armenian national holidays, Yerevan 200"]. Available at: http://geopolitika.am/dir/wpcontent/blogs.dir/1/files/2015_1_2_34_44.pdf (accessed 15 July 2020) (in Russian).

4. Shaginyan Marietta. Puteshestvie po sovetskoi Armenii. [Travel across Soviet Armenia]. Available at: https://www.litmir.me/br/?b=139187\&p=1 (accessed 22 July 2020) (in Russian).

5. Antonyan Y. Religiosity and religious identity in Armenia: Some current models and developments. Article in Acta Ethnographica Hungarica, December 2011. DOI: 10.1556/AEthn.56.2011.2.4.

6. Lisitsian S.S. Ancient dances and theatrical performances of the Armenian people.1958, No. 5, pp. 131-138.

7. Petrova J. A. Cultural and language problems faced by migrants as the members of a certain ethnic community. Science Almanac of Black Sea Region Countries. 2016. No. 1. Available at: http://science-almanac.ru/documents/72/2016-01-14-Petrova.pdf (accessed 18 July 2020).

8. Petrova Yulia A., Kemova Milana R. Adygea is a pearl of the Caucasus, national features of ethnos from origins to modernity. Science Almanac of Black Sea Region Countries. 2019. No. 4. Available at: http://science-almanac.ru/documents/285/201904-05-Kemova-Petrova.pdf (accessed 25 July 2020). 